\title{
Classification of the types and forms of loess pseudokarst
}

\author{
Andrew Lavrusevich ${ }^{1 *}$ \\ ${ }^{1}$ Moscow State University of Civil Engineering, 129337, 26, Yaroslavskoye Shosse, Moscow, Russia
}

\begin{abstract}
Loess pseudokarst in recent decades has been developing very rapidly and causes significant material damage. Every year, as a result of the development of loess pseudokarst, tens of thousands of hectares of valuable irrigated land are left out of the crop rotation. This is a very rapidly developing process (months, days, hours). Classification of types of loess pseudokarst depending on the conditions of its development is given. An augmented classification of pseudokarst relief forms based on the physical and chemical properties of the loess is also presented. A brief description of the types and forms of loess pseudokarst poorly illuminated in the literature is given. The nature of the interaction of some natural and technogenic processes with loess pseudokarst is considered.
\end{abstract}

\section{Introduction}

Pseudokarst of loess is the result of hydro-mechanical, gravitational, biological and physic-chemical destruction of the loess during their episodic (usually technogenic) flooding what causes the formation of landforms that are very reminiscent to the typical karsts (cave, dips, sinkholes, wells, gullies, circuses, tunnels, etc.)(A.Lavrusevich,2010, A.Lavrusevich, etc.2012).

Factor in the formation pseudokarst, divided into natural and technogenic. In Figure 1 and Table 1 shows and briefly describe the nature of the interaction of some natural and manmade processes loess pseudokarst (A.Lavrusevich,2018). The most intensive development of loess pseudokarst happens when human impacts on loess arrays. Under natural conditions, loess pseudokarst develops slowly and affects large areas.[1-3]

\section{Main part}

I. Types of loess pseudokarst

Under the terms of education and the impact of natural and technogenic factors are the following types of loess pseudokarst:

A - caused by features of landforms:

A1. developed along the edge of ledges regional terrace

A2. intermediate

\footnotetext{
* Corresponding author: lavrusevich@yandex.ru
} 
A3. joist or sais

A4.diveloped in the slope.

B - caused by features of the structure of loess array:

B1. associated with underground excavations of loess

B2. associated with the landslide

B3. associated with subsidence.

Give a brief description of weakly sanctified in literature types of loess pseudokarst: A4, B1 and B3.


Fig.1. The nature of the interaction of some natural and technogenic processes of loess pseudokarst. 
Table.1. Processes and the nature of their relationship with the loess pseudokarst.

\begin{tabular}{|c|c|c|c|}
\hline $\begin{array}{l}\mathrm{N} \\
\mathrm{p} / \mathrm{p}\end{array}$ & $\begin{array}{c}\text { The nature of the } \\
\text { interaction of some } \\
\text { natural and technogenic } \\
\text { processes of loess } \\
\text { pseudokarst }\end{array}$ & $\begin{array}{l}\text { Color in } \\
\text { Fig. } 1\end{array}$ & Description of processes \\
\hline 1 & $\begin{array}{l}\text { Processes that play } \\
\text { exclusively catalytic } \\
\text { role in the formation of } \\
\text { loess pseudokarst (LPK) }\end{array}$ & & $\begin{array}{l}\text { Factors weathered loess arrays. In } \\
\text { particular, biological destruction, } \\
\text { contributing to the formation of } \\
\text { underground tunnels which begins } \\
\text { penetration of water in loess and the } \\
\text { beginning of an array of suffusion, as the } \\
\text { process of forming the initial psevdokarst } \\
\text { forms in destruction of loess array. } \\
\text { Education the psevdokarst failures of } \\
\text { resulting underflooding. Pseudokarst } \\
\text { development in places where underground } \\
\text { excavation of loess. The psevdokarst } \\
\text { badlands formation in areas uncivilized } \\
\text { water discharge. }\end{array}$ \\
\hline 2 & $\begin{array}{l}\text { Processes play a } \\
\text { catalytic role in the } \\
\text { formation of loess } \\
\text { pseudokarst (LPK) and } \\
\text { the induced its } \\
\text { formation. }\end{array}$ & & $\begin{array}{l}\text { Primary education of psevdokarst } \\
\text { underground tunnels enhances erosion } \\
\text { (increase capacity moves). The process is } \\
\text { multiplicative. Landslides and rock falls in } \\
\text { loess promotes formation of deep cracks in } \\
\text { the upper part of the slope. As a result of } \\
\text { uneven subsidence while soaking formed } \\
\text { deep cracks forming of psevdokarst } \\
\text { landforms. }\end{array}$ \\
\hline 3 & $\begin{array}{l}\text { Processes induced by } \\
\text { the formation of loess } \\
\text { pseudokarst (LPK) and } \\
\text { exacerbated by its } \\
\text { development. }\end{array}$ & & $\begin{array}{l}\text { Development of psevdokarst } \\
\text { gullies, formation which occurs from the } \\
\text { top down to the base level. Increased } \\
\text { several times abrasion loess shores of } \\
\text { reservoirs affected pseudokarst. By } \\
\text { breakage array pseudokarst increases } \\
\text { seismicity loess area, which may result in } \\
\text { the display of the earthquake subsidence, } \\
\text { landslides and avalanches. }\end{array}$ \\
\hline
\end{tabular}

A4. Dedicated to the slopes of the loess type pseudokarst. Developed within the band width of 20-30 meters, stretching along the artificial pits and slopes. Pseudokarst this type, because of their "youth", is usually at the local sites of uncontrolled spillway or breach of vegetation array and presents a chain of craters of small extent and failures area of 10-20 $\mathrm{m} 2$. Timely delivery of outputs when the process dies, however, falling abnormally high rainfall, reactivated of psevdokarst process. On these forms during development of psevdokarst Michael mine KMA says L.S. Tabaksblat (1964). Figure 2. 


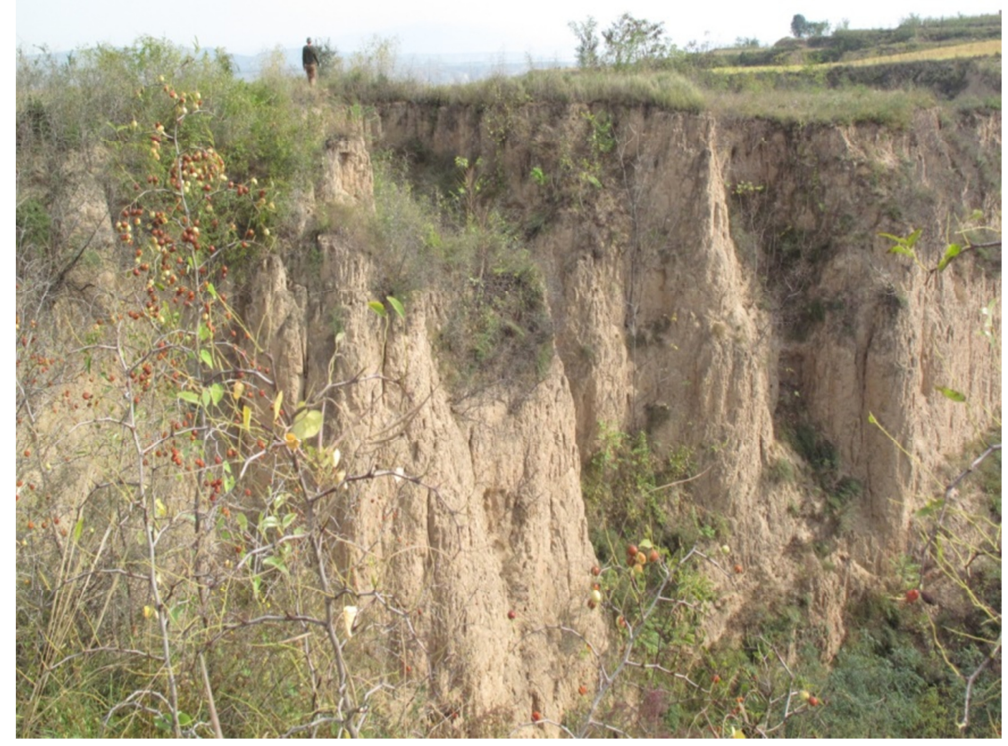

Fig. 2. Timed to curb entry trench slope brick factory (Shensi Province) loess pseudokarst presented craters, bench edge bowls, dips and small ravines. Photo A.Lavrusevich. 07.2010.

B1. Loess pseudokarst associated with underground excavation of loess. This type pseudokarst associated with the formation of erosion moves craters and valleys of the cavities in the array loess associated with human activities. These landforms are described in China, Uzbekistan and other parts of the world loess (Chalimov R.,1992, Lavrusevich A., etc., 2012 etc.) (Figure 3).



Fig. 3. The photo shows the fragments preserved, but abandoned the man cave. As a result - the failures and the total destruction of the slope pseudokarst. Photo A.Lavrusevicha. 07.2010.

In China, in areas of loess almost everywhere from prehistoric times to develop this type of "housing". This is a practical and low-cost housing is still regularly performing well. However, when a man leaves his home and builds houses, caves are deteriorating and 
break down, causing the development of loess pseudokarst. The construction of the caves leads to inconsistency loess array. Bench edge part is affected caves deep sometimes up to 60 meters in 5 meters.

B3. Type pseudokarst of loess associated with the formation of cracks in the uneven subsidence of loess soils in their areal soaking mentioned by E..Zaporozhchenko 1969, E.Skvaletsky etc. 1969, N.Kriger etc.,1983, etc . It should be noted that the subsidence is a slow, gradual increase in humidity loess over a large area. Pseudokarst necessary for the development of the water flow through cracks and trenches burrowing animals in loess array without wetting the array completely and with the removal of soil particles aqueous stream having a high kinetic energy (Kriger N. etc.,1983, Lavrusevich A. 1985) (Figure 4).



Fig. 4. Sagging blocks on the edge of a polygon is soaked with a width of cracks up to 1.5 meters Starboard Yavansu River, Tajikistan. Photo A.A.Lavrusevich. 07.1989.

II. Classification of psevdokarst landforms.

The morphology of loess pseudokarst is extremely diverse. Because of uniqueness of the physicochemical properties of loess, the karst related forms such as stalactites, stalagmites and stalognatare are not formed within pseudokarst cavities. Being many times in pseudokarts caves, the author observed on the horizontal surfaces small formations of overwatered loess with height of 5-6 sm and 4-8 sm in diameter resembling stalactites. Their further growing, as a rule, does not occur. However, abundance in various forms is typical for pseudokarst loess and in many respects similar to the typical forms of karst topography. The Classification of pseudokarst forms was proposed by N.I.Kriger in 1975 (Kriger N.1975). Based on the years of experience and studying of pseudokarst by author in Tajikistan, Uzbekistan, Russia and China, it can be modified as following.

I. Underground forms

1.Enhanced cracks

2.Narrow passage

3.Tunnels

4.Caves

5. Blind or closed cavities

II. Surface shapes

A. Depressions

1.Failures 
2.Funnels

3.Trenches

4.Bench edge bowl

B. Erosional depressions

1.Gullies

2.Circuses

3.Wells

C. Erosions

1.Ponors

2.Hanging niches

3. Niche at the base of the slope

D. Remains

1.Walls

2.Outliers

3.Bridges and arches

4.Pillars

Brief description of the newly isolated form of loess pseudokarst: 5. Blind or closed cavities and a 3-Niche at the base of the slope.

5. Blind or closed cavities.

Found where the water table fluctuations. In our opinion, these landforms are viable in loess array. Such underground cavities mentioned in the literature. In particular, these forms have been received and are described by researchers at engineering geological survey of the Krasnoyarsk aluminum plant, and were associated with suffosion or wedges ice.

However, let's assume the following scenario development process. When raising the water table (eg, caused by technogenesis), increased moisture in loess rocks that previously had low humidity, high porosity, a small amount of soluble compounds, etc. Due to capillary rise, the value of which in loess rocks can exceed several metersn (Lysenko, 1972), impaired structural integrity of rock and formed a set of collapse of small size. A further increase in the cavity does not, otherwise it will lead to the manifestation of the collapse or crater on the surface of the array. In the first case, provided that the ground water level will not rise or leaks with it goes down, it remains a closed space, potentially hazardous for agricultural development and operation of loess array or the construction of buildings.

3-Niche at the base of the slope.

A special place in the development of loess pseudokarst owned niche, emerging at the base of the loess slope (Lavrusevich A.,1987). The reasons for a niche, mostly revealed by the author in the research of loess slopes and escarpments. Try to characterize some of them. In the formation of psevdokarst failure, usually a vertical wall and on the edge of the ledge formed by overhanging ledge of turf xerophytic plants, fastening their rhizomes top layer of soil. Atmospheric deposition contribute to making the eaves of the overhanging sod falling water drops, which have a high kinetic energy. At the base of the slope, so that a zone of high humidity and by the falling water is a mechanical rejection of soil particles at the base of the slope. Is deepening niches deep repose, and when it reaches 0.3 meters, or a little more, the displacement of the overlying loess unit.

The process of forming a niche has a major importance in the evolution of vertical loess slope (Figures 5,6). 


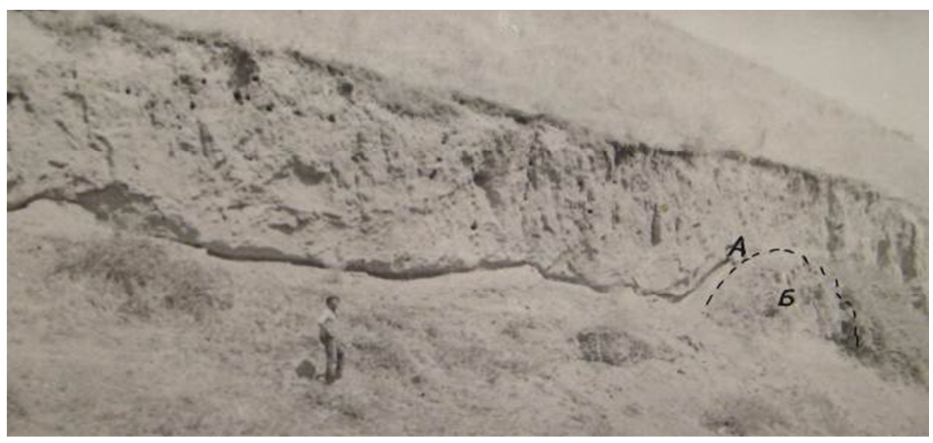

Fig. 5. Niche at the base of loess slope of low power (up to $18 \mathrm{~m}$ ). Visible displaced loess unit (B), and the beginning of a new niche in the area (A). Photo A.A.Lavrusevich. 08.1988.

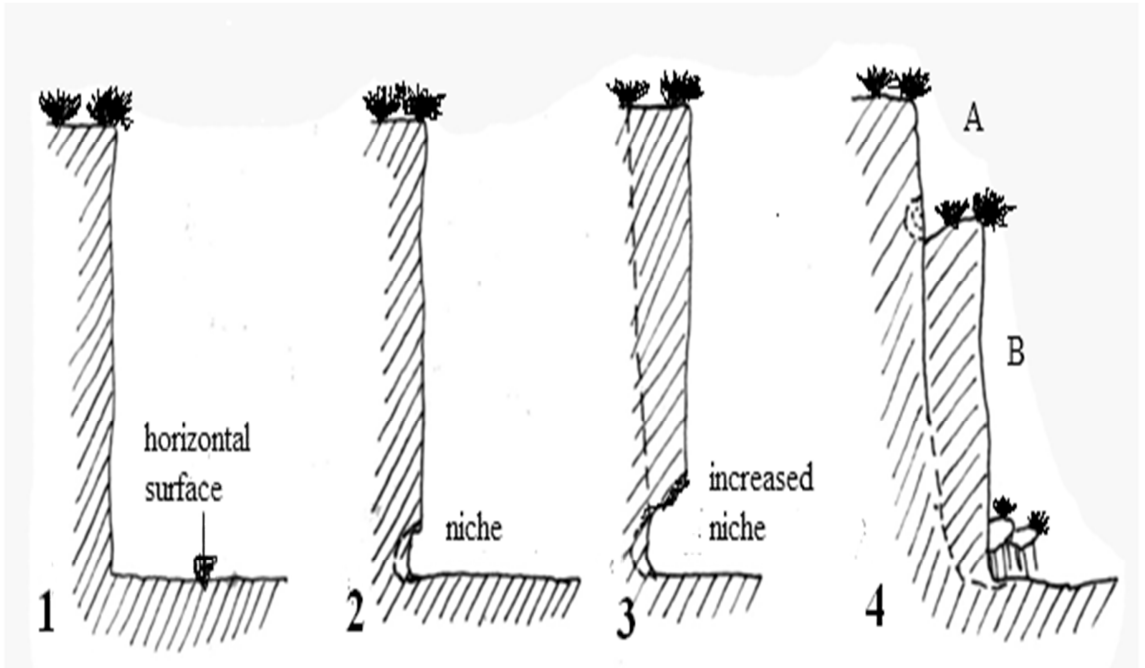

Fig. 6. Scheme of formation dynamics niche at the base of loess slope.

A similar pattern can be observed in Central Asia in the destruction of constructions built of loess. The base structures are formed on the above scheme, a niche that is a major factor in the length of "life" of technogenic structures (Figure 7).

In a study of a large number of slopes in China, the author has not found a niche formation in this region, due to the fact that at the junction of the vertical wall in a horizontal, usually grow higher plants, which are at a vertical drip drops dampen shocks and education niche happens .

\section{Conclusion}

It is useful to study the processes with morphological effects seen from the geological point of view as immediate (for decades) by using satellite images. There are examples of changing shores of reservoirs, plowing of lands, and development of loess pseudokarst. The study of loess formations using satellite images revealed the following feature. As a rule, tops of pseudokarst gullies in loess have the shape of horseshoes, or circuses. Thus, on satellite images when zoomed in, pseudokarst landforms and typically erosional landforms are very well distinguished. First time this phenomenon was observed during the mapping 
of the territory of the Javanese valley in Tajikistan affected by pseudokarst. In plane view these forms of land are fairly well distinguished by their "open works" laced together in a chevron design. Classification given by the author is constantly

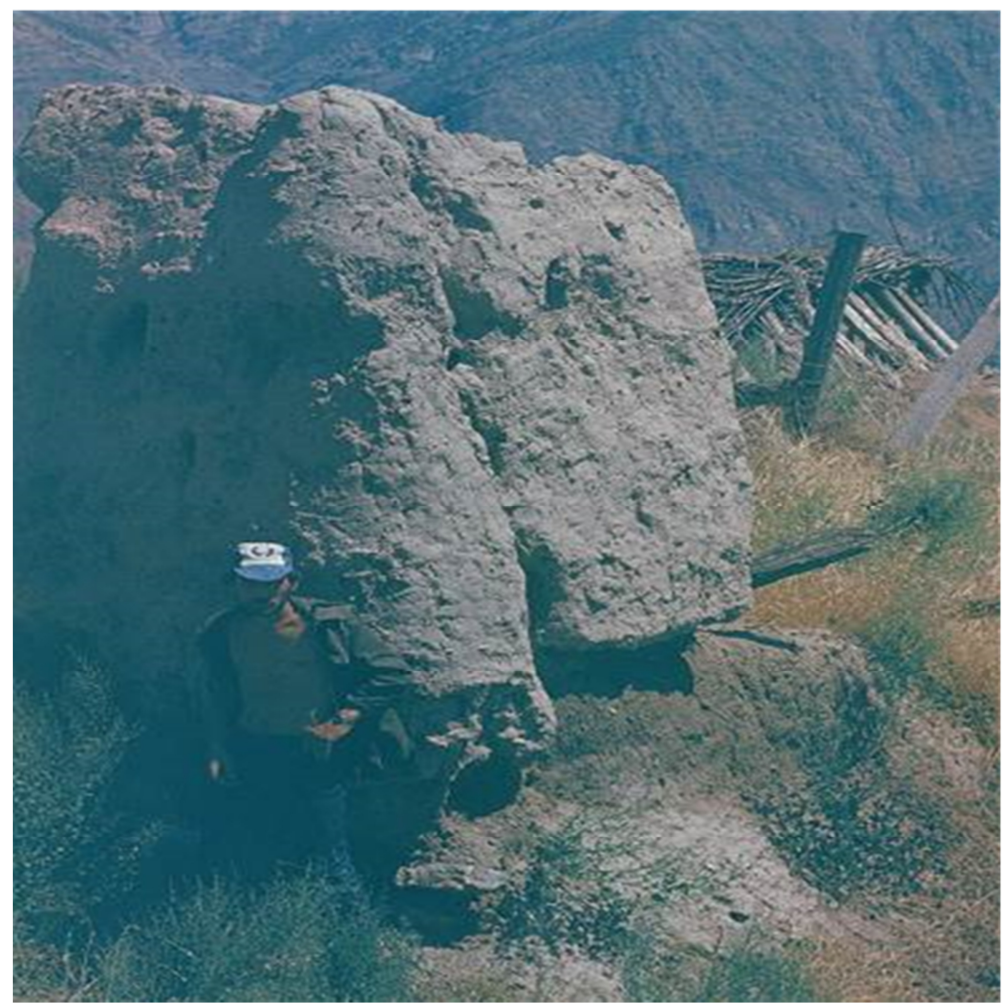

Fig. 7. Forming the basis of a niche in the clay of the fence. Noling village, starboard Nurek reservoir, Tajikistan. Photo A.A.Lavrusevich. 06.1985.

\section{References}

1. A. Lavrusevich, MATEC Web of Conferences 193, 02011 (2018).

2. A. Lavrusevich, Engin. Res. 10, 20-23(2010)

3. A. Lavrusevich, V. S. Krasheninnikov, I. A. Lavrusevich, Engin. Geol.1, 44-54 (2012) 